\title{
Evaluation of different rice genotypes for physiological and yield attributes under agro-climatic conditions of swat region Khyber Pakhtunkhwa
}

\author{
Shahid Hussain ${ }^{1,2^{*}}$, Sangar Khan ${ }^{3}$, Zhang Rui ${ }^{2}$ and Irshad Ahmad ${ }^{2}$ \\ 1. Department of Agronomy, PMAS- Arid Agriculture University Rawalpindi, 46300-Pakistan \\ 2. College of Agriculture, Yangzhou University, Yangzhou, Jiangsu 225009, P.R-China \\ 3. College of Environmental and Resources Sciences, Zhejiang University, Hangzhou 310058-China \\ *Corresponding author's email: Shahidh91@outlook.com \\ Citation
}

Shahid Hussain, Sangar Khan, Zhang Rui and Irshad Ahmad. Evaluation of different rice genotypes for physiological and yield attributes under agro-climatic conditions of swat region Khyber Pakhtunkhwa. Pure and Applied Biology. Vol. 10, Issue 1, pp26-33. http://dx.doi.org/10.19045/bspab.2021.100004

\begin{tabular}{|c|c|c|c|}
\hline Received: 14/05/2020 & Revised: 05/08/2020 & & Online First: $26 / 08 / 2020$ \\
\hline
\end{tabular}

\section{Abstract}

The experiment aims to evaluate different rice genotypes under agro-climatic condition to study physiological and grain yield contribution. Six genotypes and one variety i.e. Fakhr-eMalakand (check variety), IR64, IR8225-9-3-2-3, PK344-3-2, Cibogo, Japonica, and OM5627 were evaluated in a randomized complete block design (RCBD) with three replications. Various morphological characters were measured i.e. days to 50\% flowering, days to maturity, flag leaf area $\left(\mathrm{cm}^{2}\right)$, plant height $(\mathrm{cm})$, panicle length $(\mathrm{cm})$, tiller hill ${ }^{-1}, 1000$-grain weight $(\mathrm{g})$ and grain yield ton $\mathrm{ha}^{-1}$ with highly significant results $\left(71,121,12.6\left(\mathrm{~cm}^{2}\right), 104.8(\mathrm{~cm}), 20\right.$, $28.63(\mathrm{~cm})$ and $9.629\left(\right.$ ton $\left.\mathrm{ha}^{-1}\right)$. IR64 produced a higher number of tillers hill ${ }^{-1}(20)$ while OM5627 produced highest 1000-grain weight (28.63 g). The genotype Fakhr-e-Malakand (checked variety) has high grain yield (9.629 ton ha ${ }^{-1}$ ) followed by IR64 (9.29 ton ha ${ }^{-1}$ ) while minimum yield recorded in Japonica 5.988 ton $\mathrm{ha}^{-1}$. IR64 (9.29 ton ha ${ }^{-1}$ ) genotype produced higher grain yield than remaining genotypes i.e. PK344-3-2 (8.945 ton ha $\left.{ }^{-1}\right)$, IR8225-9-3-2-3 (8.228 ton ha ${ }^{-1}$ ), OM5627 (7.289 ton ha ${ }^{-1}$ ), Cibogo (6.820 ton ha ${ }^{-1}$ ) and Japonica (5.988 ton ha $\left.{ }^{1}\right)$ respectively. The result showed IR64 genotype will be further investigate in the farmer's field for the final approval as a commercial variety under agro-climatic condition of the swat region.

Keywords: Evaluation; Fakhr-e-Malakand; Grain yield; Khyber Pakhtunkhwa; Swat; Rice Genotypes

\section{Introduction}

Rice (Oryza sativa L.) is the world's most imperative nourishment food after wheat in Asian origin [1]. Around $75 \%$ of world rice is produced and use as the main dietary item of 3.5 billion people [2], due to an increase in populations in Asian continent, the rice demand will be increasing upto $70 \%$ by 2025 [3]. Rice has been universally cultivated in an area of 153.51 million ha with a yearly production of approximately 759.6 surpassed by $0.6 \%$ rather than 2016 [3]. According to FAO's report world rice production in 2018 yield staging a 10.3 million tons annual increase to the high of 769.9 million tons. China is the world top rice producer among the rice-producing countries (2017-2018), Pakistan is the 
eleventh number producer of rice after china and produced 208.6 million tons, India produced 166.5 million tons and Indonesia concluded estimates 73.9 million tons in 2017 with an average efficiency of 2.96 ton ha- ${ }^{-1}$ [4]. Approximately more than $80 \%$ of world population directly or indirectly depends on rice crop and enumerate as a nutritional food, which contained protein (6-12\%), carbohydrate (70-80\%), minerals (1.2-2.0\%), and a vital substance of fats and vitamins $[5,6]$. In Pakistan rice is cultivated as a food, cash crop and second preeminent exportable product after cotton. The rice cultivated region expanded by $6.4 \%$ to 2,899 thousand hectares compared to 2,724 thousand hectares comparing with last year 2017-18. The production of rice improved factually high 7442 thousand tons against the production of 6859 thousand tons and recorded an increment of $8.7 \%$ overproduction of last year. Pakistan earned 1.53 billion US\$ from rice exports, which contribute $0.7 \%$ to its GDP [7]. Punjab and Sindh province contributes $90 \%$ in total production followed by Baluchistan and Khyber Pakhtunkhwa (KP). KP major riceproducing Districts are D.I. Khan, Swat, Malakand, Dir. Lower and Dir upper \& Malakand etc. According to the statistics of KP cultivated area in 2016-17 was 66986 ton $\mathrm{ha}^{-1}$ and in 2017-2018 was 61620 ton $\mathrm{ha}^{-1}$ and consequently, production in 201617 was 15823 tons and in 2017-18 was 3147525 tons [8]. Pakistan is a well-known country for rice production; however, our cultural practices are the main reason of average low production; as compared to other countries. Pakistan initiated different methods to tackle these problems through traditional breeding of selection, crossing and mutation breeding [9]. For variety development, successful illustrations arose from traditional breeding that produced famous basmati varieties like Basmati 370, Basmati 385, and Super basmati and nonbasmati varieties such as IRRI-6, DR-82, DR-83, DR-92, JP-5, Sara Saila, Dil Rosh97, Fakhr-e-Malakand, Swat-I, and Swat-II.
It is necessary to grown better cultivars for high quality and high production [10]. Genetic variability provides genotypes that able to screen out new varieties [11]. Variability in respect to genetic could be successfully transferred to the next generation because of genetic characters [12]. Traits with high genetic indicated that these traits could be utilized in selecting upland rice for prominent enhancement [13].

The current study was carried out to identify and select potential genotypes and evaluating traits of importance for genetic improvement by exploiting the genetic variation and diversity of some agronomic attributes, yield and nutritional qualities of six rice genotypes. The locally cultivated varieties of rice are respectively susceptible to insect, pest, and diseases so the experiment was conducted to screen out the high yielding rice genotype, adoptable under the agro-climatic condition of Malakand division, with the following objectives:

1. To study the performance of different advanced genotypes against the existing commercial varieties.

2. To screen out the rice genotypes and select the most promising type for commercial release.

\section{Materials and Methods}

A field experiment was conducted at the Agriculture Research Institute, Mingora Swat during 2014-2015. It's high altitude mountainous area of Malakand division located on 34.5 to $36^{\circ} \mathrm{N}$ and 800 to $1800 \mathrm{~m}$ elevation. Temperature fluctuated from $8.5^{\circ} \mathrm{C}$ to $18.5^{\circ} \mathrm{C}$ (annual rainfall $81-88 \mathrm{~cm}$ ) during the Kharif season, soil was clay loamy which suitable for rice cultivation. Before transplantation field was prepared in watered condition and then water was applied to the field for puddling. Nursery was transplanted in prepared paddy field (watery condition) after thirty days of sowing. In well puddled field supplied a half dose of NPK @120,60, 40 kg ha ${ }^{-1}$ before transplanting and a half after one month of transplantation. Row to row and 
plant to plant distance kept $20 \mathrm{~cm}$, maintained block size $4.2 \mathrm{~m}^{2}$ with seven rows for each genotypes/variety.

\section{Statistical analysis}

The data collected were analyzed by SPSS (version 20.0); physiological parameters were subjected to the analysis of variance (ANOVA) method to find out the variance between all genotypes. Means were compared by standard error and critical value for comparison using least significant variance (LSD) test. Statistical analysis software (SPSS) was applied for computing both the LSD and ANOVA.

\section{Results and Discussion}

The data regarding days to $50 \%$ flowering as shown in (Tale 1), revealed significant difference at $(\mathrm{P} \leq 0.05)$ in all genotypes which apparent in (Figure-1). Maximum $50 \%$ flowering (71 days) was observed in Cibogo genotype while the minimum 50\% flowering was observed in Japonica (50.33 days) genotype. The remaining genotypes ranged between 63.33 and 69 days. This type of liability to vary might be due to the genetic makeup of the exotic lines and genotypic environmental factors [14]. Similarly in other studies, variation in grain quantity and quality founded significantly in different genotypes and environment interaction i.e. beans, rice, and wheat crops $[15,16]$. The maturity period ranged from 84 to 121 days. Japonica genotype showed maturity after (84 days) whereas the genotypes PK344-3-2, IR8925-9-3-2-3, and Fakhr-e-Malakand (check), taken 121 days to mature as compared to other genotypes. Evaluated twelve genotypes indicated that the early heading matured early and late heading genotypes matured late [17]. It was also reported that rice maturity decreases growth duration due to genetic control and deficit water, which ultimately related to delay flowering phase [18]. The flag leaf area (FLA) results revealed that the data among rice genotypes were significantly varied $(\mathrm{P} \leq 0.05)$ which showed in (Table 1 \& Fig. 1). FLA among rice genotypes ranged between $9.83 \mathrm{~cm}^{2}$ and $12.60 \mathrm{~cm}^{2}$ (Table $1 \&$ Fig. 1). The minimum FLA recorded in Cibogo $(9.83$ $\mathrm{cm}^{2}$ ) while the maximum FLA recorded in OM5627 (12.60 $\left.\mathrm{cm}^{2}\right)$. Similar positive associations were found in flag leaf area with 1000-grain weight, grain yield, and yield-related traits in rice cultivar [19, 20]. Flag leaf is responsible for photosynthetic products, which translocate during the grain filling stage, which directly enhances seed size [21, 22]. The researcher observed positive relations of FLA with 1000-grain weight and proposed that the improvement in flag leaf area could increase grain weight, spike length, spikelets per spike ${ }^{-1}$, grains spike ${ }^{-1}$ and 1000-grains weight [23, 24, 25]. Results concerning plant height indicated that significance $(\mathrm{P} \leq 0.05)$ variation observed among $\mathrm{PK}$ 344-3-2 $(104.8 \mathrm{~cm})$ followed by Fakhr-e-Malakand and IR8225-9-3-2-3 as given in (Table $1 \&$ Fig. 1), whereas lowest plant height observed in Japonica $(89.8 \mathrm{~cm})$. In the same manner, [26] reported that different genotypes of basmati rice observed heritability with high genetic improvement for plant height. Also, other researchers reported that plant height shows a negative correlation with yield and observed positive relationship of plant height with grain quality [27].

Data regarding panicle length indicated variation among the examined genotypes, minimum panicle length was noted in Japonica $(21.24 \mathrm{~cm})$ whereas maximum panicle length noted in OM5627 $(28.01 \mathrm{~cm})$ as specified in (Table $2 \&$ Fig. 2). Similarly, the number of panicles declined under climatic stress conditions, further described that the phenotypic performance influencing due to genetic variability [28]. 


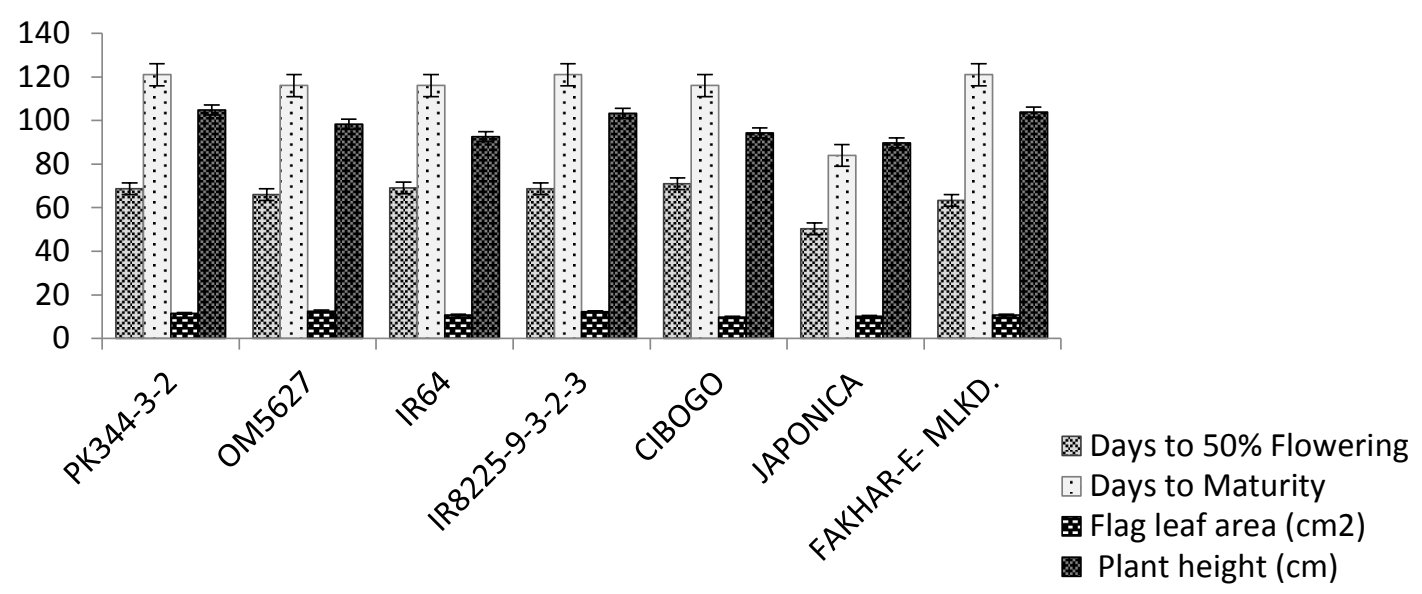

Figure 1. Vertical bars indicate standard error of days to $50 \%$ flowering, days to maturity, FLA, and plant height $(\mathrm{cm})$ in different genotypes of rice

Table 1. Relative study of different rice genotypes under agro-climatic condition of growth parameters i.e. days to $50 \%$ flowering, days to maturity, flag leaf area $\left(\mathrm{cm}^{2}\right)$, plant height $(\mathrm{cm})$ at $5 \%$ probability level (ANOVA, Fisher (LSD) test)

\begin{tabular}{|c|c|c|c|c|}
\hline Genotypes & $\begin{array}{c}\text { Days to 50\% } \\
\text { flowering }\end{array}$ & $\begin{array}{c}\text { Days to } \\
\text { Maturity }\end{array}$ & $\begin{array}{c}\text { Flag Leaf Area } \\
\left(\mathbf{c m}^{2}\right)\end{array}$ & $\begin{array}{c}\text { Plant height } \\
(\mathbf{c m})\end{array}$ \\
\hline Fakhr-e-Malakand & $63.33 \mathrm{~d}$ & $121 \mathrm{a}$ & $10.70 \mathrm{~cd}$ & $103.8 \mathrm{a}$ \\
\hline IR64 & $69.00 \mathrm{~b}$ & $116 \mathrm{~b}$ & $10.83 \mathrm{bcd}$ & $92.6 \mathrm{~cd}$ \\
\hline IR8225-9-3-2-3 & $68.67 \mathrm{~b}$ & $121 \mathrm{a}$ & $12.23 \mathrm{ab}$ & $103.2 \mathrm{a}$ \\
\hline PK344-3-2 & $68.67 \mathrm{~b}$ & $121 \mathrm{a}$ & $11.47 \mathrm{ab}$ & $104.8 \mathrm{a}$ \\
\hline Cibogo & $71.00 \mathrm{a}$ & $116 \mathrm{~b}$ & $9.83 \mathrm{~d}$ & $94.2 \mathrm{bc}$ \\
\hline Japonica & $50.33 \mathrm{e}$ & $84 \mathrm{c}$ & $10.23 \mathrm{~cd}$ & $89.8 \mathrm{~d}$ \\
\hline OM5627 & $66.00 \mathrm{c}$ & $116 \mathrm{~b}$ & $12.6 \mathrm{a}$ & $98.3 \mathrm{~b}$ \\
\hline $\begin{array}{c}\text { Critical value for } \\
\text { comparison }\end{array}$ & 0.8386 & 1.0271 & 1.4186 & 4.369 \\
\hline
\end{tabular}

The high heritability with high genetic advance genotypes was determined to increase in panicle weight and panicle length also significantly scored panicle length as evaluated 13 genotypes [29-31]. The higher number of tillers/hill observed that in IR64 (20) followed by Cibogo while the lowest number of tillers/hill observed in PK344-3-221 shown in (Table 2 \& Fig. 2). In line with this, [32] reported that the highest number of tillers hill-1 ${ }^{-1}(34)$ founded in Gomal-6 compared with Gomal-7. IR-6 also showed the maximum number of tillers per unit area [33, 34]. Statistically, thousand-grain weight increased significantly in all genotypes as showed in (Table 2 \& Fig. 2) that obtained 1000-grain weight in OM5627 (28.63g) followed by
Fakhr-e-Malakand (27.83g), IR64 (27.24g) and IR8225-9-3-2-3 (27.13g) whereas PK344-3-2 (21.13g) showed lowest 1000grain weight among the compared genotypes. In line with this, [35] statistically, the analyzed correlation and grain weight was influenced by the Flag leaf area. In uniformity of this result, other factors like, biotic and abiotic (adaptability, temperature, soil fertility, transplantation season, and time) might be responsible for thousand-grain weight. This statement agrees to the association characters of various genotypes observed in basmati rice highly significant and high genetic advance for thousand-grain weights [17]. Grain yield were obtained in the various rice genotypes which denoted in (Table 2), 
evident from that the grain yield ton per hectare was found significantly different amid all genotypes. The result showed that the highest grain yield (9.629 tons ha- $\left.{ }^{-1}\right)$ was recorded in Fakhr-e- Malakand (check variety) followed by IR64 (9.291 tons ha' ${ }^{-1}$ ) while lowest grain yield was attained by Japonica (5.988 tons $\mathrm{ha}^{-1}$ ) followed by Cibogo (6.820 tons ha ${ }^{-1}$ ), Komal genotype having $\left(4072.8 \mathrm{~kg} \mathrm{ha}^{-1}\right)$ Grain yield, whereas minimum (1885.3 $\left.\mathrm{kg} \mathrm{ha}^{-1}\right)$ Grain yield was observed in Fakhr-e-Malakand genotype which apparent in (Figure-2).
Uniformly, results founded [36] that the effective tillers/hill and number of grains/panicle produced significant grain yield/ha. Another researcher concluded adverse results founded when $2 \mathrm{C}^{0}$ of temperature increased, decreased in grain yield by $15-17 \%$ of rice [37]. Our result aligned with the study which observed adoption pattern, differential performances, and relative profitability of different rice varieties showed that Sonar Bangla (7.48 ton $\mathrm{ha}^{-1}$ ) performed better than compared varieties i.e. Alok 6201 was 5.81 ton $\mathrm{ha}^{-1}$ whereas HYV was 5.63 ton $\mathrm{ha}^{-1}[38,39]$.

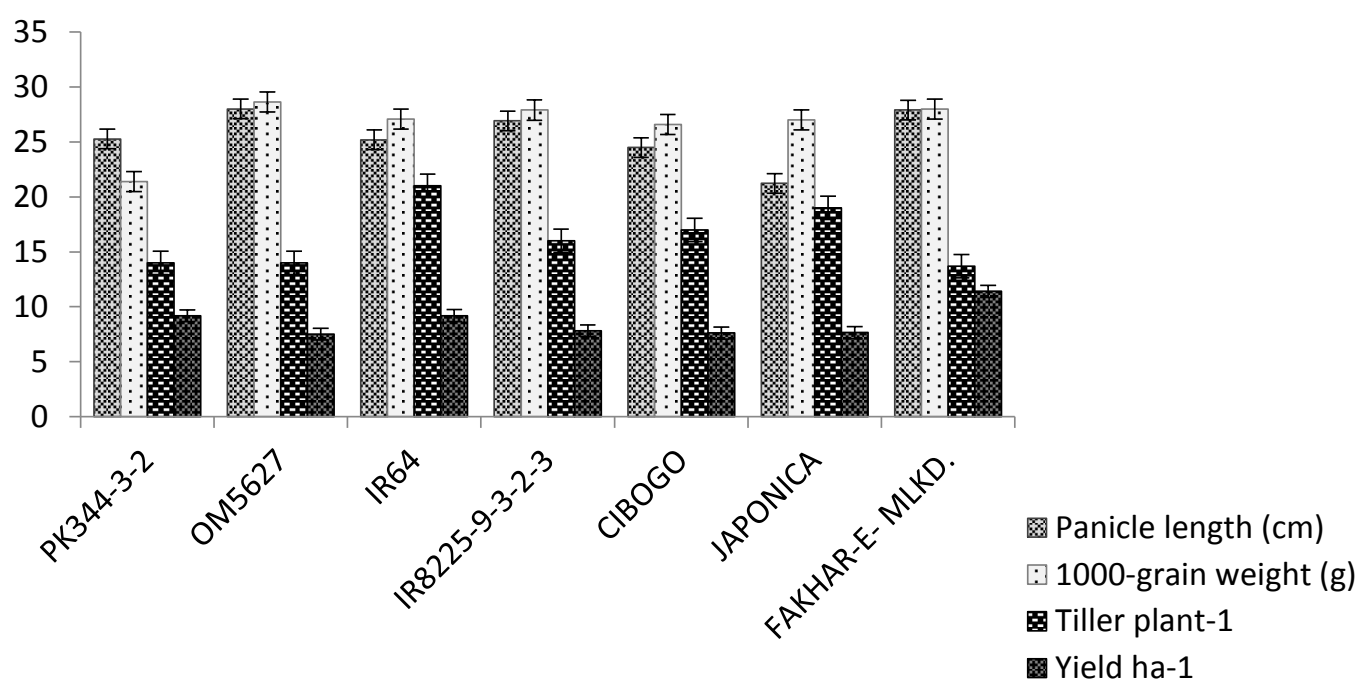

Figure 2. The vertical bars indicate standard error of panicle length, tillers hill-1, 1000grain weight, and grain yield tons $\mathrm{ha}^{-1}$ in different genotypes of rice

Table 2. Relative study of different rice genotypes under the agro-climatic condition of yield parameters i.e. panicle length, tillers hill-1, 1000-grain weight, grain yield ha-1 at $5 \%$ probability level (ANOVA, Fisher (LSD) test)

\begin{tabular}{|c|c|c|c|c|}
\hline Genotypes & $\begin{array}{c}\text { Panicle length } \\
(\mathbf{c m})\end{array}$ & Tillers hill $^{\mathbf{1}}$ & 1000-grain weight $(\mathbf{g})$ & Grain Yield ha $^{\mathbf{- 1}}$ \\
\hline Fakhr-e-Malakand & $27.87 \mathrm{a}$ & $14.7 \mathrm{bc}$ & $28.13 \mathrm{ab}$ & $9.629 \mathrm{a}$ \\
\hline IR64 & $25.22 \mathrm{ab}$ & $20.0 \mathrm{a}$ & $27.40 \mathrm{abc}$ & $9.291 \mathrm{ab}$ \\
\hline IR8225-9-3-2-3 & $26.90 \mathrm{a}$ & $16.0 \mathrm{bc}$ & $27.13 \mathrm{abc}$ & $8.228 \mathrm{bc}$ \\
\hline PK344-3-2 & $25.26 \mathrm{ab}$ & $13.7 \mathrm{c}$ & $21.07 \mathrm{~d}$ & $8.945 \mathrm{ab}$ \\
\hline Cibogo & $24.60 \mathrm{ab}$ & $16.7 \mathrm{abc}$ & $25.60 \mathrm{bc}$ & $6.820 \mathrm{de}$ \\
\hline Japonica & $21.24 \mathrm{~b}$ & $17.7 \mathrm{bc}$ & $25.00 \mathrm{c}$ & $5.988 \mathrm{e}$ \\
\hline OM5627 & $28.01 \mathrm{a}$ & $14.3 \mathrm{bc}$ & $28.63 \mathrm{a}$ & $7.289 \mathrm{~cd}$ \\
\hline $\begin{array}{c}\text { Critical value for } \\
\text { comparison }\end{array}$ & 4.3429 & 3.5756 & 2.756 & 0.4414 \\
\hline
\end{tabular}




\section{Conclusion}

The present study manifested that the influence of climatic on rice genotypes was significant for days to $50 \%$ flowering, days to maturity, flag leaf area $\left(\mathrm{cm}^{2}\right)$, plant height $(\mathrm{cm})$, panicle length $(\mathrm{cm})$, tiller hill ${ }^{-}$ ${ }^{1}, 1000$-grain weight $(\mathrm{g})$ and grain yield (ton $\mathrm{ha}^{-1}$ ). Amongst all tested genotypes, after Fakhr-e-Malakand (check variety), IR64 and IR8225-9-3-2-3 performed as highest yielding genotypes at Malakand climate condition as compared to other genotypes. IR-64 genotype yielded ( 9.29 ton ha ${ }^{-1}$ ) and will be recommended as a commercial variety after further screening for adaptation of yield-related traits.

\section{Authors' contributions}

Conceived and designed the experiments: $\mathrm{S}$ Hussain, Performed the experiments: $S$ Hussain, Analyzed the data: Z Rui, contributed materials/ analysis/ tools: $S$ Khan \& I Ahmad, Wrote the paper: S Hussain.

\section{Acknowledgment}

We are thankful to Agricultural Research Institute (North) Mingora, for providing us necessary facilities for experiment.

\section{References}

1. Lindnera S, Xue W, Nay-Htoonb B, Choic J, Egea Y, Lichtenwalda N, Fischera F, Koc J, Tenhunena J \& Otienoa D (2016). Canopy Scale CO2 Exchange and Productivity of Transplanted Paddy and Direct Seeded Rainfed Rice Production Systems in S. Korea. Agri For Meteorol 228: 229238.

2. Bouman BAM, Lampayan RM \& Tuong TP (2007). Water Management in Irrigated Rice: Coping with Water Scarcity. International Rice Research Institute, Los Banos (Philippines). pp. 54.

3. FAO (2018). Global Information and Early Warning System. Rice Market Monitor, V. XXI, No. 1 and GIEWS.

4. Oko A, Ubi B \& Efisue A (2012). Comparative analysis of the chemical nutrient composition of selected local and newly introduced rice varieties grown in Ebonyi state of Nigeria. IJAF 2: 16-23.

5. Hossain MS, Singh AK \& Fasih-uzZaman (2009). Cooking and eating characteristics of some newly identified inter sub-specific (indica/ japonica) rice hybrids. Sci Asia 35: 320-25.

6. Govt. of Pakistan (2015). Economic Survey of Pakistan 2014-2015. Finance Division, Economic. Advisory Wing, Islamabad, Pakistan. pp. 21.

7. Crops Statistics (2018). Crop reporting services Agri., Livestock and Cooperative Dept., Govt. of Khyber Pakhtunkhwa.

8. Osman KA, Mustafa AM \& Ali F (2012). Genetic variability for yield and related attributes of upland rice genotypes in semi-arid zone (Sudan). Afr J Agric Res 7(33): 4613-19.

9. Khurram B, Khan NM, Rasheed S \& Salim M (2007). Indica rice varietal development in Pakistan: an overview. Paddy Water Envi 5: 73-81.

10. Pandey $\mathrm{P}$, John $\mathrm{P} \&$ Anurag DK (2009). Genetic variability, diversity and association of quantitative traits with grain yield in rice (Oryza sativa L.). J Biol Sci 17(1): 77-82.

11. Akinwale M, Gregorio G \& Nwilene F (2011). Heritability and correlation coefficient analysis for yield and its components in rice (Oryza sativa L.). Afr J Plant Sci 5: 207-12.

12. Akinola TF, Odiyi AC \& Fayeun LS (2019). Genetic variability and genetic diversity of 13 upland rice genotypes for agronomic traits and nutritional qualities. J Agric Sci Bot 3(1): 6-11.

13. Feila $S$, Mosera B \& Jampatongb $S$ (2005). Mineral composition of the grains of tropical maize varieties as affected by preanthesis drought and rate of nitrogen fertilization. Crop Sci 45: 516-23.

14. Zada A, Ahmad, Ali A, Junaid M, Habib N \& Rahman J (2014). Performance of Different Rice Genotypes in the Cold Climatic Region 
of Malakand Division. J Natl Sci Res 4(23).

15. Welch RM \& Graham RD (2002). Breeding crops for enhanced micronutrient content. Plant Soil 245(1): 205-14.

16. Sabouri H, Rabiei B \& Fazalalipour M (2008). Use of selection indices based on multivariate analysis for improving grain yield in rice. Rice Sci 15 (4): 303 310.

17. Abarshahr M, Rabiei B \& Lahigi SH (2011). Assessing genetic diversity of rice varieties under drought stress conditions. Nat Sci Biol 3(1): 114-123.

18. Zahid AM, Akhtar M, Anwar M \& Jamal A (2005) a. Genotypic and Phenotypic. Correlation and Path Analysis in Coarse Grain Rice. Proceedings of the International Seminar on Rice Crop. Rice Res Inst, Kala Shah Kau, Pakistan.

19. Ashraf-uzzaman MM, Islam R, Ismail MR, Shahidullah SM \& Hanafi MM (2009). Evaluation of six aromatic rice varieties for yield and yield contributing characters. Int J Agric Biol 11: 616-620.

20. Prakash M, Anandan A \& Kumar BS (2011). Varietal variations inflag leaf area and yield in mutant lines of PY 5 rice. Karnataka J Agric Sci 24: 525526.

21. El-Mohsen AAA, Hegazy SRA \& Taha MH (2011). Genotypic and phenotypic interrelationships among yield and yield components in Egyptian bread wheat genotypes. $J$ Plant Breed Crop Sci 4: 9-16.

22. Kalimullah S, Khan J, Irfaq $M$ \& Rahman H (2012). Genetic variability, correlation and diversity studies in bread wheat (Triticum aestivum L.) germplasm. J Anim Plant Sci 22: 330333.

23. Degewione A, Dejene $T \&$ Sharif $M$ 2013. Genetic variability and traits association in bread wheat (Triticum aestivum L.) genotypes. Int Res J Agric Sci 1: 19-29.
24. Desheva G (2016). Correlation and path-coefficient analysis of quantitative characters in winter bread wheat varieties. Trakia J Sci 1: 24-29.

25. Ghallab KH, Sharaan AAN \& Ismail SKA (2017). Estimation of genotypic and phenotypic correlations for some growth traits and grain yield of Wheat genotypes. Int J Agron Agric Res 10: 53-58.

26. Zahid AM, Akhtar M, Sabar M, Anwar M \& Ahmad M (2005). Interrelationship among Yield and Economic Traits in Fine Grain Rice. Proceedings of the International Seminar on Rice Crop. October 2-3. Rice Research Institute, Kala Shah Kau, Pakistan. pp. 21-24.

27. Lafitte $\mathrm{HR}, \mathrm{Li} Z \mathrm{ZK}$, Vijaya kumar CHM, Gao YM, Shi Y, Xu JL, Fu BY, Yu SB, Ali AJ, Domingo J, Maghirang R, Torres R \& Mackill D (2006). Improvement of rice drought tolerance through backcross breeding: Evaluation of donors and selection in drought nurseries. Field Crops Res 97: 77-86.

28. Jahn CE, Mckay JK \& Mauleon $\mathrm{R}$ (2001). Genetic variation in biomass traits among 20 diverse rice varieties. Plant Physiol 155(1): 157- 168.

29. Vange T (2009). Biometrical studies on genetic diversity of some upland rice (Oryza sativa L.) Accessions. Nat Sci Res 7(1).

30. Laxuman L, Salimath P \& Shashidhar $H$ (2010). Analysis of genetic variability in interspecific backcross inbred lines in rice (Oryza sativa L.). Karnataka J Agric Sci 23: 563-65.

31. Worede F, Sreewongchai T \& Phumichai C (2014). Multivariate analysis of genetic diversity among some rice genotypes using morphoagronomic traits. J Plant Sci 9(1): 1424.

32. Saifullah S, Hussan G, Ahmad SQ and Ahmad F (2002). Genotypic performance of rice in Pakhal plains of Mansehra. Sarhad J Agric 18: 49-52. 
33. Awan TH, Ali RI, Manzoor Z, Ahmad M \& Akhtar M (2011). Effect of different nitrogen levels and row spacing on the performance of newly evolved medium grain rice variety, KSK-133. J Anim Plant Sci 21(2): 231234.

34. Sasaki R, Yamaguchi H \& Matsuba K (1999). Theoretical analysis of the tillering capacity for the lower density of seedling establishment in direct seeding cultivation of rice (Oryza sativa L.). Jpn J Crop Sci 68(1): 10-15.

35. Bharali B \& Chandra K ((1994). Effect of low light on dry matter production, harvest index and grain yield of rice (Oryza sativa L.) in wet season. NeoBotanica 2(1): 11-14.
36. Biswas JK, Hossain MA, Sarker BC, Hassan M \& Haque MZ (1998). Yield performance of several rice varieties seeded directly as late aman crops. Bangladesh J. Life Sci 10: 47-52.

37. Aggarwal PK \& Mall RK (2002). Climate change and rice yields in diverse agro-environments of India. II. Effect of uncertainties in scenarios and crop models on impact assessment. Clim Change 52: 331-343.

38. Kim JK, \& Krishnan HB (2002). Making Rice a Perfect Food: Tuning Dreams into Reality. J Crop Prod 5: 93-130.

39. Hossain M, Janaiah A \& Husain M (2003). Hybrid Rice in Bangladesh Farm-Level Performance. Econ Political Wkly 38(25): 2517-2522. 